\title{
Global Financial Derivatives Market Development and Trading on the Example of Ukraine
}

\author{
George Abuselidze ${ }^{1, *}$, Nadiia Reznik ${ }^{2}$, Anna Slobodianyk ${ }^{3}$, and Victoria Prokhorova ${ }^{4}$ \\ ${ }^{1}$ Batumi Shota Rustaveli State University, Georgia \\ ${ }^{2}$ National University of Life and Environmental Science of Ukraine, Ukraine \\ ${ }^{3}$ National University of Life and Environmental Science of Ukraine, Ukraine \\ ${ }^{4}$ Ukrainian Engineering and Pedagogical Academy, Ukraine
}

\begin{abstract}
Stock market of financial derivatives in Ukraine still develops. There is important to find the way how to use world experience for the domestic implementation. First of all there is a need to improve of legislative base to ensure economic and financial stability. The next way of integration process for domestic stock market of financial derivatives is stock consolidation. Before implementation of foreign experience on the stock market of Ukraine it is important to take into account of all risks which are connected with this process. This research shows appropriate steps for integration of Ukrainian stock market of financial derivatives into global scale. The article identifies the economic essence of derivatives and their types within market economy. Key trends in global derivatives trading are highlighted. Current state and organizational measures of derivatives market development in Ukraine are discussed. Price risk has become the main feature of contemporary commodity and financial markets. Globalization of world commodity and financial markets leads to rapid changes and uncertain business conditions. Under current circumstances, derivatives market provides efficient ways for price risk hedging within market economy. That is why it is important to take into consideration the contemporary state and perspectives of derivatives market in Ukraine.
\end{abstract}

\section{Introduction}

Globalization of the world markets gradually was turned into reality. E-Commerce technologies by stock exchange financial derivatives, in particular on electronic stock exchanges, make it necessary to reconsider the traditional concepts of functioning and development of the stock market of financial derivatives. There is emerging of a new more mobile legal environment and the transformational structures of investors cause the formation of qualitative models of development and the financial market. The global derivatives market is a main pillar of the international financial system and the economy as a whole. Today, businesses around the world use derivatives to effectively hedge risks and

* corresponding author : george.abuselidze@bsu.edu.ge 
reduce uncertainty about future prices. Derivatives contribute to economic growth and increase the efficiency of markets by improving price discovery for assets [23].

Modern stock mechanisms and principles of trading on world stock exchanges require the development of other financial derivatives and trade rules. The process of consolidation, the creation of new trading platforms, alternative exchange trading systems and increased competition have sharply changed. Stronger competition increases the threat of bankruptcy, which induces the manager to work harder to avoid liquidation and to keep his job [25]. Specifically, Kothari [15] finds that financial reporting conveys substantial information to outsiders about firm performance that significantly influences market expectations and stock prices. The transformational evolution of the monetary and financial stock exchanges today is manifested through the expansion of the range of new services - from the possibility of concluding transactions on the platforms of electronic stock exchanges till a comprehensive financial and economic analysis of the work of listed companies and other assets. In this regard, the study of the prospects for the development of global stock exchange trading by financial derivatives don't disappeared in the domestic financial market, causing new transformations to it if to take into account the fact that the transformations in the modern world as a result of globalization [5].

At present the main factors, which have influence on the stock market of financial derivatives, are next: the transformation the of modern technologies' structure; the transformation of infrastructure according requirements of private investors; the growth of competitive advantages between traditional and high-tech trading exchange systems.

New competitive principles, which exist on the domestic and world stock markets of financial derivatives, require the search for new competitive strategies in these conditions.

\section{Methods}

The literature is related to the types of financial innovations of the markets. Empirical studies have examined the problems associated with the regulation of the securities market were considered mainly in the context of the regulation of the entire financial system [8]. For instance, the effect of institutional ownership on innovation [3], analyst coverage [12], credit supply [4], stock liquidity [9], leveraged buyouts [16], investment failure and tolerance [23], the decision to go public [6] and the stages of development of financial markets [14].

Analytical market reviews, materials of periodicals, resources of the Internet are the informational and methodological basis of the measures of legislative regulation on the stock market of financial derivatives in Ukraine. However, the present study attempts to show the economic essence of derivatives as risk management tools, the emergence of derivatives market in Ukraine, the volume of trading, the types of exchange derivatives instruments, trends and future prospects of derivatives market in Ukraine.

\section{Results and Discussions}

\subsection{Improvement of legislative regulation on the stock market of financial derivatives in Ukraine}

One of the real leverage of the country's economy is to attract investments, the most accepted and practical form of investing in securities through the stock market [2]. A fully fledged stock market of financial derivatives can become a mechanism for ensuring economic and financial stability, as well as conducting the necessary transformational changes on the path to world integration, particularly in the conditions of reforming in the economic system of Ukraine. 
The slow development of the stock market of financial derivatives in the country significantly reduces the competitiveness of Ukraine on the market of foreign investment capital. The stock market of financial derivatives in Ukraine is still in its infancy. In the short history of its formation the necessary infrastructure has already been built up by the joint efforts of state institutions and market participants, a certain legislative framework has been established, and large-scale propaganda work is being conducted to attract domestic investors of individuals and legal entities towards the possibilities of investment in financial derivatives. However, world experience shows that it is impossible to successfully achieve the progressive development of stock trade by financial derivatives in Ukraine as the main source of accumulation of investment capital that is necessary for the creation and development of business in the absence of a full and consistent state policy which is aimed at improving the regulation of this financial segment [7]. It should be noted, that in recent years the key trend in the world derivatives market was the transition of derivative trade from OTC-market to exchanges and clearing houses. However, globalization and exchanges mergers also require liberalization of regulatory requirements and increased investors' protection. In contrast to the global derivatives market annual growth, derivatives market in Ukraine needs to be improved in the nearest future.

The level of development of the financial derivative' market has long been an important indicator of the competitiveness of any country's economy as well as Ukraine. The stage is on the agenda of with modern in global competitiveness and economic sovereignty of the interoperability problem, which, in turn, organically linked to the economic security of Independent States [1]. Thus, one of the components which has influence on the indicators of the Global Competitiveness Index of all countries of the world (calculated by the World Economic Forum) remains a set of indicators of the development of financial markets in countries.

The clause on the opening and closing of a position is not legally regulated, because closing of positions is the delivery by assets or offset. Offset is the opposite position of the futures when the seller has to buy and the buyer has to sell. Consequently, the amount of open deals in futures trade is equal to the difference between the number of purchased and sold futures. It is interesting that only $2-5 \%$ of deals are closed by deliveries. In order to prevent speculation on the stock exchanges, limits for the rejection of the current day's futures prices for the previous day's price quotation are set for each type of contract. The need for legislative regulation is also required for options, because in the world practice there is the so-called American option, it must be repaid at any time before the expressions, that is, it is given a term in which the buyer can close the option, the European option should be repaid on only one date of expressions (maturity, date of execution).

Therefore, there is a need for a legal definition of various types of operations with options, namely: straddle - together for the sale and purchase operations with call and put options on the same basic goods with the same price strike and the date of termination of contracts; strangle - the sale or purchase of call or put options on the same basic assets with the same terms of termination of contracts, but with different price of execution; spread - is an option operation, whereby income is formed by the difference between the premium for the sold option and the premium paid for the purchased option. It is necessary to legally identify all types of transactions with financial derivatives with the help of world experts in order to protect the best interests of participants in financial derivatives markets. Global derivatives markets have long been using alternative instruments, such as contracts for difference, over-the-counter options [13]. Situation at Ukrainian commodity derivatives market has not changed since that. Today the government agency Agrarian fond is using forward contracts in agricultural intervention program. In the past 10 years, Ukrainian commodity exchanges have not implemented any futures or options on commodity assets. 
Today Ukrainian Exchange is the leading stock exchange at the domestic derivatives market [22].

According to the Bank for International Settlements, the volume of stock derivatives is in 6 times smaller than the volume of over-the-counter derivatives that are traded on the over-the-counter market. Since such instruments become novelties for domestic legislation, the markets for alternative financial derivatives should be studied in more detail, as lack of definitions may have negatively influence on the stock market. The absence of an authorized state body that regulates and controls the derivatives market poses a threat for direction of investment resources not to the real sector of the economy, but to speculative sectors of the securities market and banking sectors. It is necessary to develop requirements for market participants of financial derivatives, in particular for stock and commodity exchanges, issuers of financial derivatives, clearing houses, traders, banks, etc. Thus, summing up the above, it can be concluded that Ukraine now needs to develop and adopt appropriate legislation that would comprehensively regulate all aspects which are related to financial derivatives taking into account foreign experience and peculiarities of domestic financial market participants.

With the improvement of regulation of stock trading by financial derivatives in the country need: to develop the state conception of the system of legal regulation of stock trading by financial derivatives and stock infrastructure, while it is necessary to improve it on the basis of world economic practice of stock trade by derivatives in terms of its adaptation to the economic conditions of Ukraine; to build stock and over-the-counter markets of financial derivatives, both in the direction of state and self-regulation; to include futures, options, swaps and instruments of financial engineering into legal regulation of the market of financial derivatives, so the legal regulation of derivatives circulation should be comprehensive for a large number of objects and subjects of the stock market, identifying new ones rights and obligations, taking into account those that existed before; to develop the system of legal regulation of financial derivatives and an analysis of its needs which require revision of legislation according to other areas and branches of law; to develop legislative regulation of the circulation of financial derivatives that requires specific knowledge, experience and analysis not only in jurisprudence. There is a need for prediction of economic, political, and other consequences of the proposed system; to define fundamental approach for the creation of a regulation system of the circulation of financial derivatives which needs to be determined and whether it will be improved on the basis and principles of the current legislation of Ukraine, or will separately be developed a system of legal regulation that requires adoption of new laws and regulations and the introduction of fundamental changes and additions to existing ones [11].

\subsection{Improvement of Ukrainian stock market with the help of stock consolidation}

The use of foreign experience of trade by financial derivatives in Ukraine is a prerequisite for effective implementation for the integration processes on the financial market of Ukraine into the world economic space and strengthening of international monetary and financial relations. An urgent need for Ukraine is the improvement of the financial market and the segment of stock market of financial derivatives, which will enable stabilization of the national economy when it enters the global space.

The further development of stock and over-the-counter markets of financial derivatives depends directly on the effectiveness of the allocation of effective approaches to the foreign experience of the functioning of the financial derivatives market. In view of this, it will be expedient to study the most optimal for the introduction of foreign experience in certain 
stages of the formation of financial derivatives markets, taking into account the current national specifics of the economy.

A large number of financial derivatives and simultaneously different hybrids are in circulation along with the main financial assets (stocks and bonds) in the world practice on the financial market. Financial derivatives on world markets are generally not issued for the purchase of additional capital but in order to hedge the risks of possible losses from the ownership of the underlying financial assets [17]. In order to update justice in the financial market, it is necessary to improve its regulation by market methods and maximize the use of free trade opportunities. Changing the landmarks of stock exchanges for investors' interests will improve the situation on the stock market [20]. The most popular financial derivatives on the world's leading stock exchanges, which are now fully used in practice, are futures, options, swaps, swap options. Futures (futures) provide the opportunity to buy or sell any financial instrument in the future at prices fixed at the time of execution of futures contracts. A security paper does not necessarily have to be as the main basis: it may be interest rates, foreign currency, fiscal or credit payments, etc.

The option is also largely similar to the futures, but its execution is not required if you are a buyer. That is, he gives his owner the right, but does not impose on him the duties of execution of transactions. In the last two decades, the stock market of financial derivatives was characterized by radical transformations and rapid growth. Consolidation processes is an important condition for the development of the global stock market of financial derivatives in modern conditions [18]. The derivatives market has recently attracted more attention against the backdrop of the financial crisis, fraud cases and the near failure of some market participants. Although the financial crisis has primarily been caused by structured credit-linked securities that are not derivatives, policy makers and regulators have started to think about strengthening regulation due to increase transparency and safety both for derivatives and other financial instruments [19]. Therefore, the improvement of the domestic financial derivatives market should also begin with the study of the peculiarities of the processes of world stock exchange consolidation with the aim to introduce this feature in the practice of the domestic stock market.

It should be noted that the tendency of consolidation or merger of the world stock exchanges on the financial market began as a result of the emergence of a tight competition for the best technological equipment, which resulted in the transformation of stock exchanges into share ownership form. This provided the sale of shares and the attraction of investments in the development of stock exchanges. Such a process was initiated in the late nineteenth and twentieth century. Generally, mixed investment policy analysis is based on historic data [10].

The international derivatives market is very dynamic and has quickly developed into the most important segment of the financial market. Competing for business, both derivatives exchanges and OTC providers, which by far account for the largest part of the market, have fuelled growth by constant product and technology innovation. The competitive landscape has been especially dynamic in Europe, which has seen numerous market entries in the last decades. For instance strong European players have emerged that today account for around 44 percent of the global market in terms of notional amount outstanding. In terms of globalize world financial markets, volatility of global financial system and increased competition the necessity to analyze market trends derivatives increases.

For the first time the acquisition of the German stock exchange Deutsche Terminborse (DTB) and the Swiss Options and Financial Futures Exchange took place in 1998, at the same time the new electronic stock exchange EUREX was appeared - it is the first world's international stock exchange on the market of financial assets.

The formation of new stock exchanges unions was the first manifestation of the consolidation process on the stock market of financial derivatives. Special news was not so 
much the appearance of the stock exchange, but the speed of its further development. EUREX need only for the year to become the world's largest financial derivatives stock exchange by the results of trades in 1999. Today EUREX provides the market with a wide range of financial derivatives of the global level and cooperates with the most liquid securities - shares and fixed income bonds, provides inexpensive and open access to its electronic platforms. The participants of this stock exchange are in 700 different places of the globe, the volume of trades on this stock exchange EUREX is annually exceeded 1.5 billion contracts.

Since 2007 EUREX has merged International Securities Exchange Inc. The new member of the EUREX group has become an electronic trading platform where financial derivatives are traded on stock indexes and shares. In addition to electronic trading, EUREX provides market participants with clearing services through the center EUREX Clearing AG for financial derivative contracts traded on EUREX, bonds and Repo operations, and, at the same time, for financial instruments of the Irish Stock Exchange and the Frankfurt Stock Exchange. Another striking example of the consolidation of world stock and commodity stock exchanges was the merger of the Paris, Amsterdam, Brussels stock exchanges in 2000 into the united pan-European stock exchange EURONEXT. Since 2002 EURONEXT has joined the London International Stock Exchange Futures and Options and also the Portuguese Stock Exchange.

The electronic stock exchange OMX AB was appeared in 2003 due to the merger of stock exchanges of Stockholm and Helsinki. The Copenhagen Stock Exchange joined in it next two years. The London Stock Exchange together with the Italian Borsa Italiana also united in 2007. The New York Stock Exchange (NYSE) merged with the major operator of the electronic trading system Archipelago Holdings Inc. in 2006. The NYSE Group has gained new opportunities in electronic trading, particularly over-the-counter instruments. This new global stock exchange combines traditional exchange trade with a new electronic trade system. The US stock exchanges NYSE, NASDAQ and AMEX are linked by electronic systems and transmit information on quotes for purchase and sale positions.

The next stage of global consolidation is the intercontinental level. It began in 1999, when was signed an agreement about the merger of two trade systems on the leading international financial derivatives exchanges EUREX - CBOT (The Chicago Board of Trade), which started its work in 2000. EURONEXT merged with the London International Financial Futures and Options Exchange in 2002. EURONEXT LIFFE merged with NYSE in 2007.

Another example of an intercontinental merger is the Intercontinental Exchange (ICE) as well as the formation of the world's largest stock exchange - the Chicago Commodity Group (CME Group).

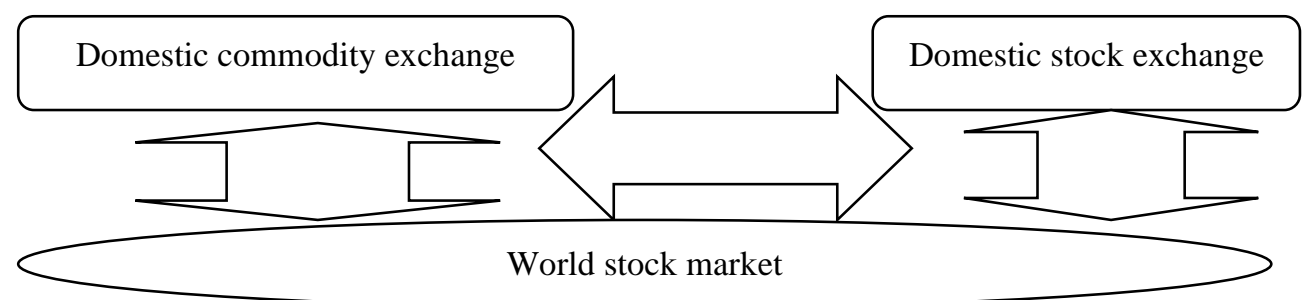

Fig. 1. The scheme of stock consolidation

Consequently, the trend of global consolidation through the merger of electronic stock exchanges of financial derivatives continues causing interest and study of this process (fig. $1)$. 
The experience of consolidation processes on the global stock market will be a vivid example and one of the first steps towards the development of the domestic stock market of financial derivatives.

\subsection{Financial risk management which is based on financial derivatives}

The global financial crisis has clearly identified and reinforced the role of financial risks. The study of international practice has shown that the main financial risks on the stock exchange are in some way related to the work of trade infrastructure. In other words, stock risks arise precisely when it comes to close contracts. International practice now identifies such major types of risks.

First of all, this is the risk of a failure of any financial system in the event of bankruptcy of its emerging and systemically important financial institutions, the so-called systemic risk. There is no single specific definition for systemic risk.

In addition to systemic risks, the US Federal Reserve has identified the following four main risks in payment, clearing and settlement systems (fig. 2) credit risk is the risk which occurs when one party of the stock exchange for some reason does not fulfill its obligations in its operation in full and for a certain period; liquidity risk, liquidity fall risk or liquidity lowering risk - which occurs in the event that one of party of the contract at a specified time does not fulfill its obligations in full due to a temporary lack of funds.

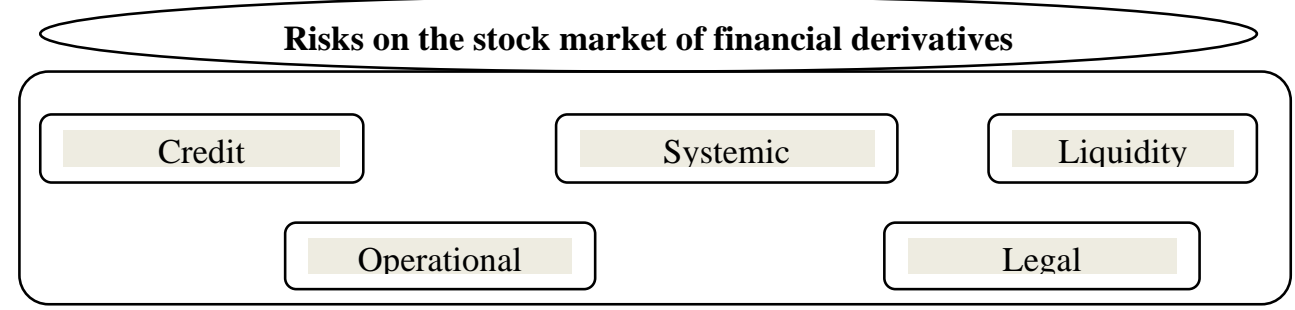

Fig. 2. Classification of risks.

The liquidity risk differs from the credit because it is not a consequence of the insolvency of the party, because there is a possibility that it will repay the debt in the near future; operational risks arising from an unforeseen situation associated with the operation of information and communication facilities, in particular human error, technical failure of software or other means or systems of communication, as well as hacking or terrorist attacks on systems; legal risk is a risk of loss due to unexpected changes, the enactment or repeal of legislative or other standards or due to the impossibility of enforcing contracts in a compulsory legal order.

In the case of «Lehman Brothers» bankruptcy in 2008, a working group from the study of the situation has found that no one seriously manage risk agreements which are concluded in the post-trade infrastructure. It was in 2008, when the financial crisis has already entered into force, the Chairman of the Board of Governors of the Federal Reserve asked for Congressional authority to oversee systemically important payment, clearing and settlement systems, arguing that the fact that many major central banks around the world already has such powers established by law. However, the stability of financial systems is constantly expanding and demands that key payment, clearing and settlement systems continuously worked in stressful situations and to effectively manage the risks of default of counterparties [21].

What about the post-trade infrastructure, the legislation of foreign countries defined it through the concepts of payment, clearing and settlement activities as activities carried out by one or more financial institutions in order to facilitate closing of financial transactions. At the same time, the term "financial transactions" included, among other things, money 
transfers, futures contracts and securities, repo, foreign exchange contracts, contracts with derivative financial instruments and swaps. The activities of payment, clearing and settlement did not include any offers or sales of securities, or any pre-trade operations, or the implementation of quotation procedures or issuance of orders at tenders.

The center of post-trading infrastructure, whose activities are aimed at creating mechanisms for guaranteed performance of concluded stock exchange transactions, is clearing. In most countries with a developed market economy, clearing is a licensed type of activity and is a subject of strict state control.

Independent legal companies carry out clearing through electronic interaction with organized and regulated markets, including with stock exchanges. As a rule, a clearing organization is a large joint-stock company; banks, investment institutions and other financial organizations are its main shareholders. Such clearing organizations provide clearing to several large stock exchanges. For example, there are the largest clearing organizations, such as Clear stream, Euro clear, EUREX Clearing and others.

High efficiency with minimal risks is achieved through netting systems: only $4-5 \%$ of transactions require a real move of financial assets or cash. Approximately, from the middle 1980s, post-trade services began to use the principle of multiple clearing sessions during the working day, which allowed to break down the daily interval for several short periods, to track operatively the situation in the systems and minimize failures. In the future, realtime settlements were implemented in most of the trade assets.

High turnovers also lead to low costs, which allow acceptable level of commission for clients who are professional participants of financial market. At the same time, the system of calculations is quite reliable; the risks of non-fulfillment of obligations under the agreements are tiny. This is achieved by the use of the following methods: calculations are conducted only in condition of "supply against payment", both sides of the transaction must have enough money on the accounts in these systems to conclude their obligations sufficiently; preliminary reconciliation of parameters of all operations (number and value of assets, which involved in trade); the use of cross-cutting data processing with automatic recognition of the results of the operation. In particular, Euro clear and Clear stream have jointly developed validation and verification systems that carry out an analysis on the day when the transactions are carrying out, and subsequently systems of reconciliation which is implementing in the immediate aftermath of operations; coverage for operations in case of shortage or absence of relevant securities or cash in the account of participants. Coverage is provided from a guarantee fund, which is formed at the expense of participants' funds, and the system itself serves as a kind of manager, which gives and returns resources, writes down and accrues remuneration, manages existing risks. Funds are returned to the accounts of creditors at the first request for payment of interest on its use. The repayment of funds is guaranteed both by the system itself and by the banks with which the guarantee agreements have been signed.

As can be seen from the foregoing, in the general sense, clearing involves the collection, processing, verification and correction of information, which relates to mutual obligations of the two parties of the agreements, the definition of these obligations and ensuring its implementation. Execution can be achieved by netting and offsetting the mutual obligations of the agreement's parties, and, if necessary, using guarantee funds for these purposes.

Thus, the main instruments of risk management on the financial derivatives market should be the construction of efficient and effective clearing and settlement system. Based on the definition of clearing, there is a need to establish clearinghouse on the domestic stock market of financial derivatives to provide insurance and guarantee all risks, which arise from financial derivatives settlements. The experience of European countries in this direction must play an important role. 


\section{Conclusions}

As a result of institutional reforms in Ukraine, the main purpose of which is the formation of a civilized economy of a market type, the stock market of financial derivatives began to play an important role.

At this stage, this segment in Ukraine has already been formed in a certain way: there are trade stock exchange electronic systems, securities issuers, numerous investment companies and banks, as well as state and municipal organizations, and there are investors who are interested in the best for their placement. The stock market of financial derivatives is a special institutional form of the financial market, in which the exchange assets of the highest quality (securities, currency, precious metals, etc.) are rotated, and transactions are carried out by professional participants. The stock exchange serves as a trading, professional, as well as regulatory and technological core of the stock market of financial derivatives.

Taking into account the peculiarities of the domestic stock market of financial derivatives, the following definition can be formulated: the stock exchange is a necessary component of a market infrastructure, which creates a concentration and centralization of financial derivatives, that in turn allows the formation of an economically justified price due to exchange-based mechanisms of formation transparent pricing, insurance and forecasting.

The economic potential of the stock market of financial derivatives does not appear simultaneously as a result of legislative acts. This potential is gradually formed as a complex of market opportunities, competitive advantages, means and sources of development of stock exchanges. The formation of the economic potential of the stock market of financial derivatives involves the implementation of a set of agreed organizational and economic transformations, which are carried out with the active support of regulatory bodies.

Prospects for the development of the national stock market of financial derivatives and its integration into world markets will largely be defined by the direction in which the improvement of the economic, financial, organizational and legal basis for the development of its information infrastructure will go.

\section{References}

1. G. Abuselidze, Global Competitiveness and Economic Sovereignty of Some Compatibility Issues with Modern Conditions. Proceedings of the International Conference on Critical Issues in Business and Economics (ICIBE 2014), (2014).

2. G. Abuselidze, Georgia's Capital Market: Functioning Problems and Development Directions in Association with European Union. Journal of Applied Economic Sciences 13, 7 (2018).

3. P. Aghion, J. Van Reenen, L. Zingales, Innovation and institutional ownership. American Economic Review 103, 1 (2013).

4. M. D. Amore, C. Schneider, A. Zaldokas, Credit supply and corporate innovation. Journal of Financial Economics 109, 3 (2013).

5. T. Andersen, D. Dobrev, E. Schaumburg, Integrated quarticity estimation: Theory and practical implementation (John Wiley \& Sons, 2012).

6. S. Bernstein, Does going public affect innovation? The Journal of Finance 70, 4 (2015). 
7. O. Chernyak, High-frequency trade as the latest technology of financial markets. Bulletin of the University of Banking of the National Bank of Ukraine 2, 17 (2013).

8. F. J. Fabozzi, F. Modigliani, M. G. Ferri, Foundations of Financial Markets and Institutions. The Journal of Finance, 49, 4 (1994).

9. V. W. Fang, X. Tian, S. Tice, Does stock liquidity enhance or impede firm innovation? The Journal of Finance 69, 5 (2014).

10. S. A. Gaurav, M. K. Harry, Hedge Fund Performance 1990-2000: Do the "Money Machines" Really Add Value? Journal of Financial and Quantitative Analysis 38, 2 (2003).

11. L. K. Grant, Trading Risk: Enhanced Profitability through Risk Control 218, (John Wiley \& Sons, 2014).

12. J. J. He, X. Tian, The dark side of analyst coverage: The case of innovation. Journal of Financial Economics 109, 3 (2013).

13. H. Hong, J. Wang, Trading and returns under periodic market closures. The Journal of Finance 55, 1 (2007).

14. P. H. Hsu, X. Tian, Y. Xu, Financial development and innovation: Cross-country evidence. Journal of Financial Economics 112, 1 (2014).

15. S. Kothari, Capital markets research in accounting. Journal of Accounting and Economics 31, 1-3 (2001).

16. J. Lerner, M. Sorensen, P. Stromberg, Private equity and long-run investment: The case of innovation. The Journal of Finance 66, 2 (2011).

17. M. Mancino, S. Sanfelici, Estimation of quarticity with high frequency data. Quantitative Finance 4, 12 (2012).

18. S. Mikhailov, U. Noegel, Heston's stochastic volatility model implementation, calibration and some extensions (John Wiley and Sons, 2004).

19. U. Motorniuk, M. Terebukh, V. Kharchuk, Development trends of the international derivatives market. Econtechmod. An International Quarterly Journal 5, 1 (2016).

20. N. Reznik. L Pankratova, High-frequency trade as a component of algorithmic trading: market consequences. ICTERI Workshops, (2018).

21. K. R. Narang, Inside the Black Box: The Simple Truth About Quantitative Trading (1 ${ }^{\text {st }}$ ed. John Wiley \& Sons, 2009).

22. State Statistics Service of Ukraine. General reports on the activity of stock exchanges in Ukraine for the years 2002-2018 (2019).

23. The Global Derivatives Market - A Blueprint for Market Safety and Integrity (Deutsche Börse AG, 2009).

24. X. Tian, T. Y. Wang, Tolerance for failure and corporate innovation. Review of Financial Studies 27, 1 (2014).

25. K. M. Schmidt, Managerial incentives and product market competition. The Review of Economic Studies 64, 2 (1997). 